\title{
Ruptured intradiploic dermoid cyst overlying the torcular herophili
}

\section{Pęknięta torbiel skórzasta w śródkościu nad spływem zatok}

\author{
Salih Gulsen, Cem Yilmaz, Comert Serhat, Nur Altinors
}

Department of Neurosurgery, Baskent University, Ankara, Turkey

Neurologia i Neurochirurgia Polska 2010; 44, 3: 308-313

\begin{abstract}
We present a 22-month-old boy with a ruptured dermoid cyst overlying the torcular herophili. The cyst had caused scalp erosion and a lytic bone lesion and was successfully excised surgically. The general features of these cysts are discussed, along with the surgical procedure and implications of cyst rupture.
\end{abstract}

Key words: chronic inflammation, posterior fossa, ruptured dermoid cyst, surgery.

\section{Introduction}

Dermoid cysts arise from the inclusion of ectodermally committed cells at the time of neural groove closure between the third and fifth weeks of embryonic life, resulting in a heterotopia of such elements [1]. Another hypothesis advocates that development of intracranial dermoid cysts depends on mesodermal nest cells dysembryogenetically adherent to primitive veins [2]. Only one case of malignant transformation of a dermoid cyst has been reported so far [3].

Dermoid cysts are benign lesions and are seen rarely - intracranial dermoids are estimated to account for $0.04 \%$ to $0.25 \%$ of all intracranial neoplasms [4-8]. Intracranial dermoid cysts are four to ten times less com-

\section{Streszczenie}

Przedstawiono przypadek dotyczący 22-miesięcznego chłopca z pękniętą torbielą skórzastą leżącą nad spływem zatok. Torbiel powodowała zmiany owłosionej skóry głowy i uszkodzenie kości. Została w całości wycięta. Omówiono ogólne cechy tych torbieli wraz z postępowaniem chirurgicznym i następstwami pęknięcia torbieli.

Słowa kluczowe: przewlekłe zapalenie, tylny dół czaszki, pęknięta torbiel skórzasta, leczenie chirurgiczne.

mon than intracranial epidermoid tumours $[4,5]$. Rupture of an intracranial dermoid cyst is extremely rare with about 60 cases in the literature [7,9-11]. We present this case to explain the clinical and surgical effects of rupture of a dermoid cyst overlying the torcular herophili.

\section{Case report}

A 22-month-old boy was brought to our clinic complaining of a lump overlying the external occipital protuberance that had increased in size within the last 2 months. Neurological examination disclosed no neurological deficits. The lump was located just above the external occipital protuberance with a size of $25 \times 20 \mathrm{~mm}$ and showed no sign of infection. Blood

Correspondence address: Salih Gulsen, maresal Fevzi Cakmak Cad. 10. sokak no 45, 06490 Bahcelievler, Ankara, Turkey, phone: 009031221268 68/1362, fax: 009031222373 33, e-mail: salihgulsen07@gmail.com

Received: 16.09.2009; accepted: 2.02.2010 
chemistry and haematological parameters were within normal limits. Sedimentation rate was $10 \mathrm{~mm}$ in 1 hour and C-reactive protein level was $1 \mathrm{mg} / \mathrm{L}$. Contrast-enhanced computed tomography (CT) demonstrated a hypodense mass overlying the torcular herophili causing bone erosion with no contrast enhancement and no vascular connection between the lesion and any intracranial venous structure (Fig. 1). Magnetic resonance imaging (MRI) displayed an $18 \times 10 \times 12 \mathrm{~mm}$ lesion overlying the torcular herophili. The dermoid cyst appeared hypointense on axial and sagittal T1-weighted magnetic resonance images without contrast enhancement, and exhibited a hyperintense appearance on coronal T2-weighted images (Figs. 2 and 3).

During surgery, a U-shaped skin flap was performed around the lesion located in the posterior fossa. Thick, yellowish fluid content including hair follicles and cellular debris was aspirated while the scalp was dissected from the skull. The dermoid cyst had ruptured and the scalp and bone tissue eroded (Fig. 4A). Posterior fossa craniectomy was performed until normal bone was reached to determine the border of the dermoid cyst. All tumour content was evacuated. The cyst capsule was adherent to the torcular herophili and scalp and was dis- sected from these structures. The scalp part of the capsule was thicker than that of the torcular herophili. The scalp, except the skin, was eroded. There was only adherence to the torcular herophili and no encroachment (Fig. 4B). The scalp part of the capsule was completely removed, but part of the torcular herophili section was left behind on this structure. Cranioplasty was performed to protect the torcular herophili.

Histopathological studies revealed a cyst wall containing stratified squamous epithelium and lamellar keratinous structure consistent with a dermoid cyst. In addition, some areas of the specimen showed chronic inflammatory changes including multinucleated foreign-body giant cells (Fig. 5 A, B). The immediate postoperative course was uneventful, and the patient was discharged without any problems on the second postoperative day.

\section{Discussion}

Liu and associates reported 8 cases of ruptured intracranial dermoid cysts that represented only $0.18 \%$ of all central nervous system tumours operated on during a 12 -year period at their institution [10]. They sugge-
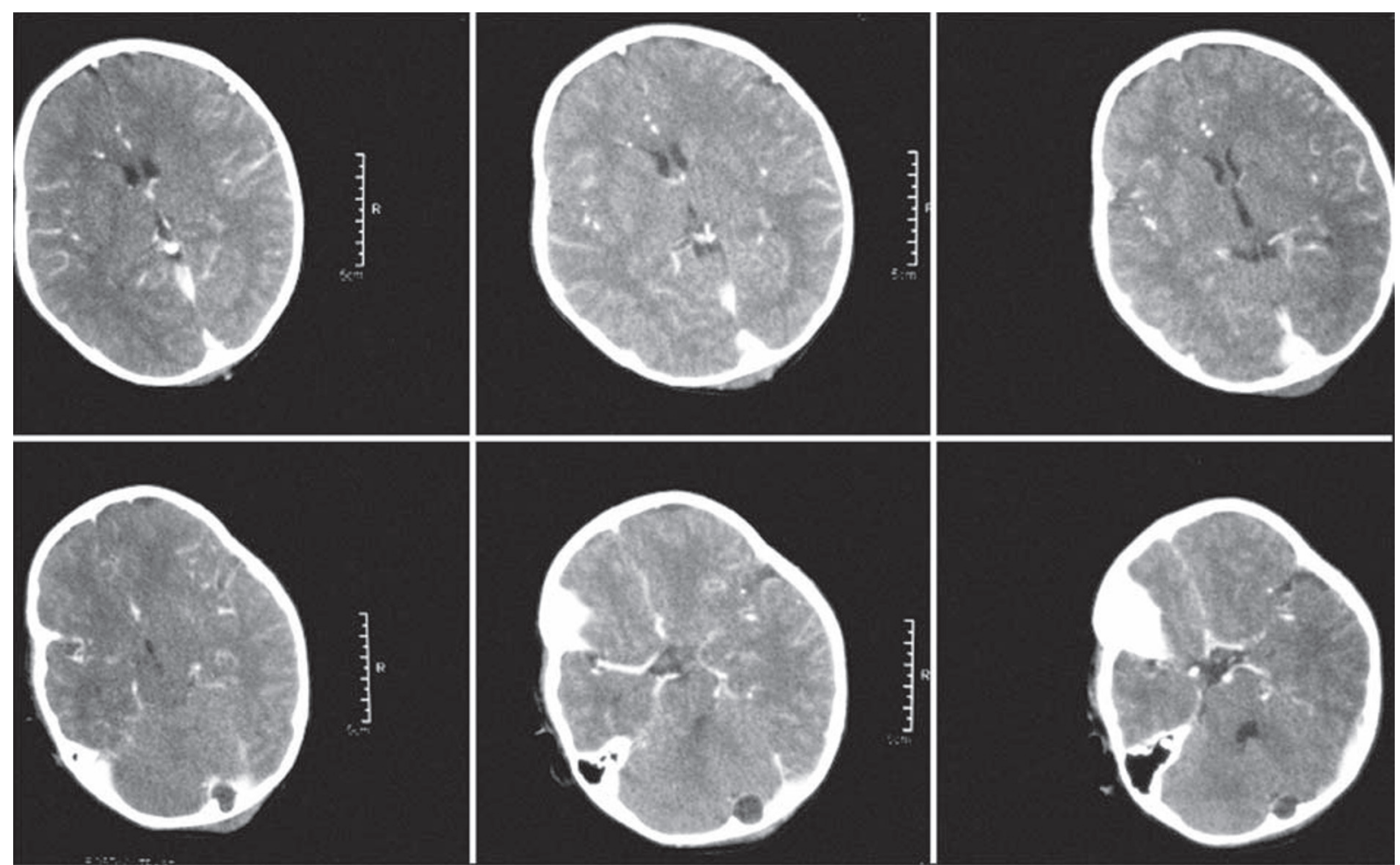

Fig. 1. Contrast-enhanced computed tomography demonstrating a hypodense mass overlying the torcular herophili causing bone erosion. There was no contrast enhancement and no vascular connection between the lesion and any intracranial venous structure 
sted that residual cyst capsules adherent to neurovascular structures be left behind to minimize the risk of complications, but they achieved gross total resection in most cases [10]. It is logical to leave behind some capsule located in critical areas as dermoid cysts have a much lower recurrence rate than epidermoid tumours and neurovascular injury may occur while removing all the capsule $[4,7,8,12]$. Liu and associates reported one case of recurrence after subtotal resection in their series [10].

Dermoid cysts consist of a capsule formed of simple epithelium supported by collagen. Hair follicles, and sebaceous and apocrine glands are also present within a dermoid cyst. They tend to enlarge and rupture early due to active production of hair and oils by the dermal appendages $[2,11,13,14]$. However, the exact pathophysiological mechanism of dermoid cyst rupture is unknown. Rupture may occur spontaneously or following closed head trauma $[5,13]$. Stendel and associates hypothesized that glandular secretions, possibly increased by age-dependent hormonal changes, may lead to rapid enlargement and rupture of these cysts [15]. Rupture of a dermoid cyst leads to spillage of contents that may
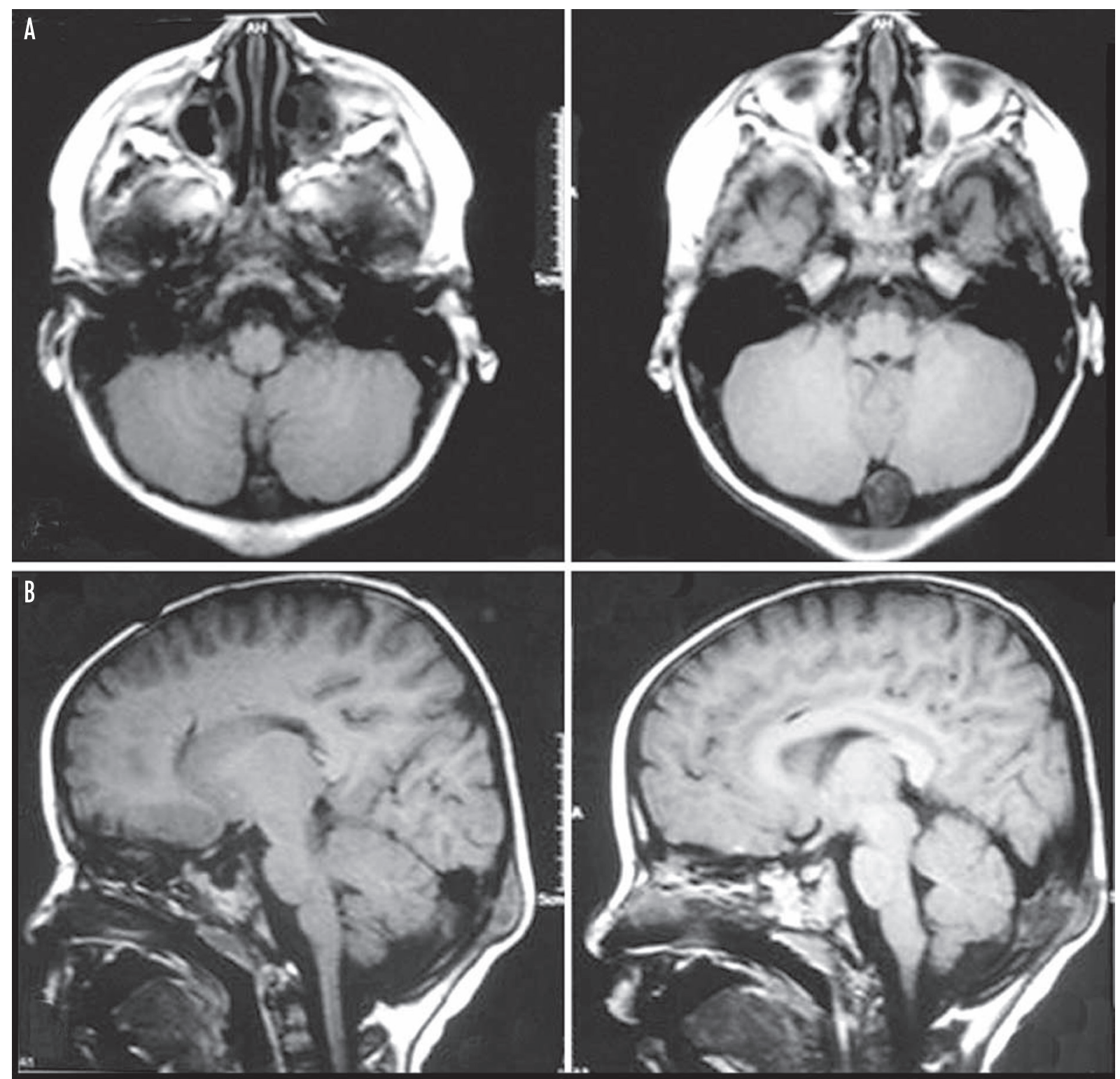

Fig. 2. Axial Tl-weighted (A) and sagittal Tl-weighted (B) magnetic resonance imaging displaying an $18 \times 10 \times 12 \mathrm{~mm}$ lesion overlying the torcular herophili. It appeared hypointense on Tl-weighted magnetic resonance images with no contrast enhancement 

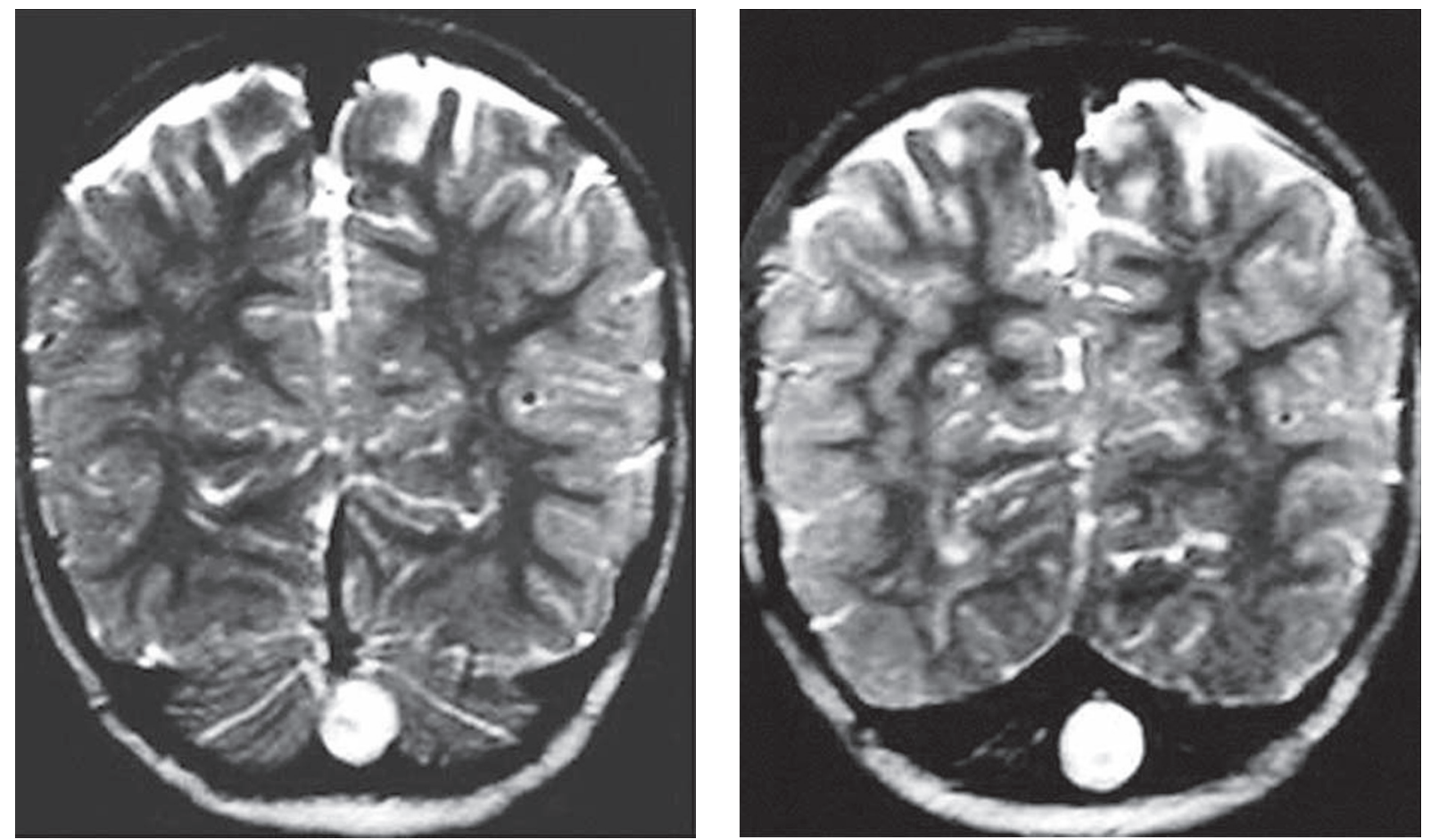

Fig. 3. Coronal T2-weighted magnetic resonance imaging displaying an $18 \times 10 \times 12 \mathrm{~mm}$ lesion overlying the torcular herophili. It appeared hyperintense on T2-weighted magnetic resonance images with no contrast enhancement
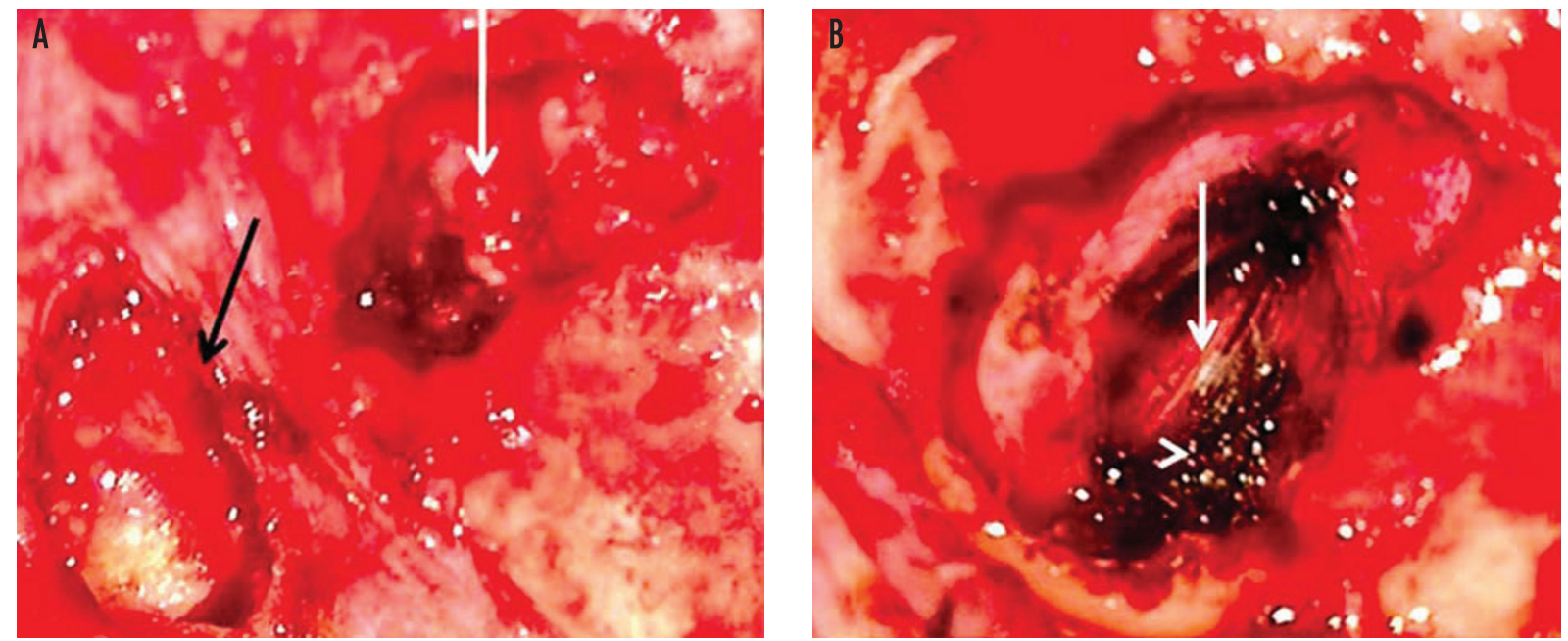

Fig. 4. (A) Intraoperative picture of the operation zone showing the eroded area of the scalp and partly excised part of the bone defect. The white arrow shows the inside of the cyst and cellular debris while the black arrow shows the eroded part of the scalp except skin due to the chronic inflammatory reaction; (B) the torcular herophili is seen following evacuation of the dermoid cyst, but a part of the dermoid cyst capsule was left behind on the torcular herophili after bipolar coagulation. The arrow shows the torcular herophili while the arrowhead shows the residual part of the dermoid cyst capsule that was coagulated with the bipolar

create an inflammatory response, chemical meningitis, recurrent meningitis, abscess formation, extradural empyema, increased intracranial pressure and seizure [2,14-17]. Dermoid cysts located at the posterior fossa have been classified according to whether their connec- tion is intradural or extradural and the presence and degree of development of a dermal sinus (whether absent, partial, or complete). This classification is as follows: group 1 - extradural dermoid cyst with a complete sinus; group 2 - intradural dermoid cyst without a der- 

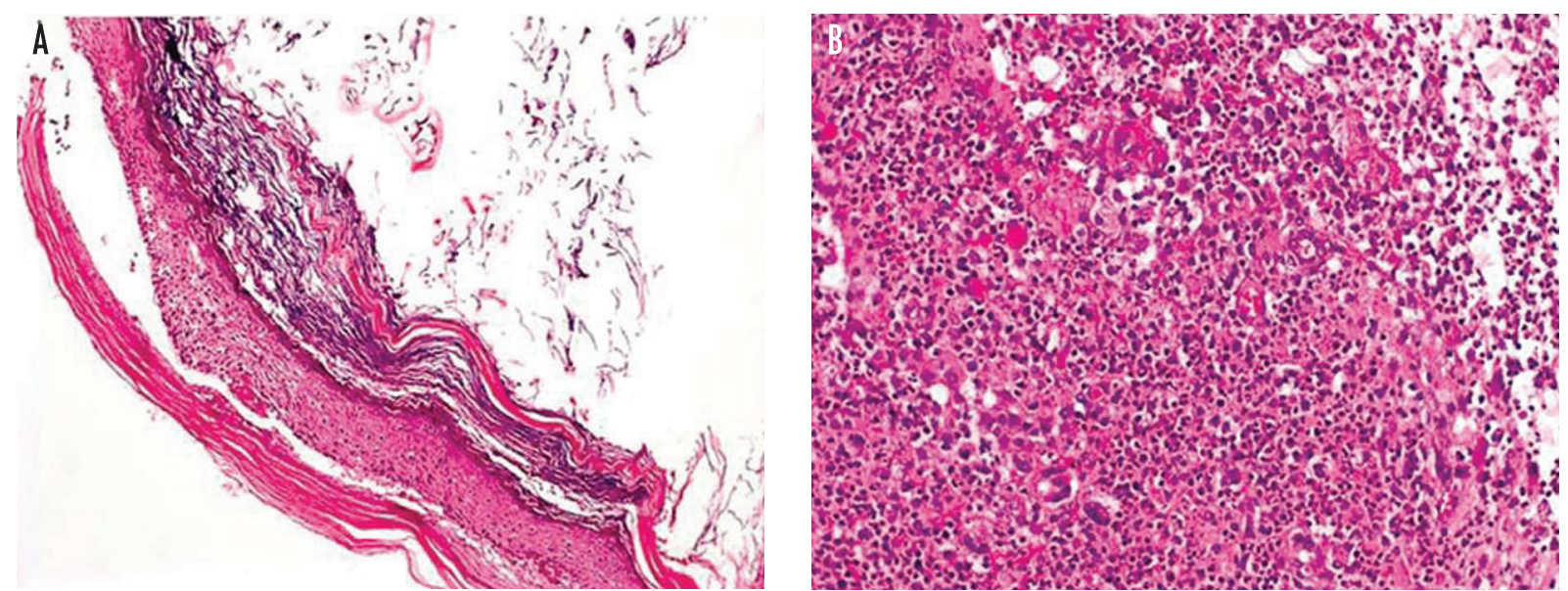

Fig. 5. (A) Photomicrograph of the specimen shows a cyst wall containing stratified squamous epithelium and lamellar keratinous structure consistent with a dermoid cyst (H\&E, original magnification $\times 100$ ). (B) Photomicrograph of the specimen shows chronic inflammatory changes including multinucleated foreign-body giant cells $(H \& E$, original magnification $\times 200)$

mal sinus; group 3 - intradural dermoid cyst with an incomplete dermal sinus; and group 4 - intradural dermoid cyst with a complete dermal sinus [18]. We were not able to find a sinus tract associated with the dermoid cyst in our presented case, but the cyst had destroyed bone and scalp tissue except the skin layer of the scalp just over the torcular herophili. We believe that the dermal sinus tract may have been destroyed due to the inflammatory response. We were therefore unable to classify this case according to the description of Goffin and associates [18]. This case could be accepted as an intradiploically located ruptured dermoid cyst. Post-surgical mortality (11\%) and severe neurological deficits (7\%) have been reported in dermoid cysts located in the posterior fossa [19]. Mortality and morbidity rates increase if meningitis (chemical or bacterial) develops [19]. Early surgical treatment gives the best results $[15,20]$. During surgery, vigorous effort to remove the capsule of a dermoid cyst overlying the torcular herophili may result in rapid and fatal exsanguination as a consequence of unanticipated connection between the dermal sinus and the torcular herophili $[1,21]$. In addition, we believe that a chronic inflammatory reaction may increase the adherence of the capsule to the torcular herophili and increase the fragility of the torcular herophili and venous structures in cases with a ruptured dermoid cyst. Fatal haemorrhage may therefore occur without a vigorous attempt to remove a ruptured dermoid cyst capsule that has no dermal sinus connection with the venous structures. MRI and CT showed a lytic bone lesion and midline localization and the rela- tionship between the lump and the torcular herophili. Our preliminary diagnosis was dermoid cyst because of its features on CT and MRI [22]. However, we did not find any evidence regarding whether the dermoid cyst had ruptured on these images. We decided to perform surgical excision of the lump rather than to follow up the patient, because of the important complications of untreated dermoid cysts located in the posterior fossa $[1,14,17]$. While dissecting the scalp from the calvarium, we reached the bone defect overlying the torcular herophili and noticed that the dermoid cyst was ruptured and had eroded all scalp layers except the skin layer of the scalp. We evacuated the dermoid cyst content that consisted of cellular debris and hair follicles. We then tried to excise the capsule that was adherent to the torcular herophili but left a small part behind as we did not want to cause rupture of the torcular herophili. We believe that the chronic inflammatory reaction created by a ruptured dermoid cyst may cause tissues to become more fragile and consequently even normal dissection may lead to damage to the venous sinus and torcular herophili. Chronic inflammatory changes were confirmed with histopathological analysis of the specimen. We believe that a ruptured dermoid cyst causes destruction of the tissues located around it and therefore the best choice is surgical excision of dermoid cysts located at the posterior fossa before they rupture. It must be noted that fragility of the tissues due to a chronic inflammatory response may lead to unanticipated bleeding during dissection of the capsule in cases with a ruptured dermoid cyst. 


\section{Conclusion}

Dermoid cysts located in the posterior fossa need proper evaluation regarding dermal sinus connection with the torcular herophili or venous sinus. A ruptured dermoid cyst causes erosion of the tissues located just around it and may lead to suppurative infection, cerebellar abscess and penetration of the venous sinus and torcular herophili. These cysts are best excised when diagnosed and one must be prepared for unanticipated venous encroachment due to the inflammatory process in cases with a ruptured dermoid cyst.

\section{Disclosure}

Authors report no conflict of interest.

\section{References}

1. Schijman E., Monges J., Cragnaz R. Congenital dermal sinuses, dermoid and epidermoid cysts of the posterior fossa. Childs Nerv Syst 1986; 2: 83-89.

2. Lunardi P., Missori P., Rizzo A., et al. Chemical meningitis in ruptured intracranial dermoid. Case report and review of the literature. Surg Neurol 1989; 32: 449-452.

3. Gluszcz A. A cancer arising in a dermoid of the brain. J Neuropathol Exp Neurol 1962; 21: 383-387.

4. Arseni C., Dãnãilã L., Constantinescu A.I., et al. Cerebral dermoid tumours. Neurochirurgia (Stuttg) 1976; 19: 104-114.

5. Bucciero A., De Caro M.L., Tedeschi E., et al. Intracranial epidermoid and dermoid cysts. Results of microneurosurgery. Minerva Chir 1997; 52: 863-866.

6. Funke M. Ruptured intracranial dermoid as an incidental finding. Aktuelle Radiol 1995; 5: 232-234.

7. Guidetti B., Gagliardi F.M. Epidermoid and dermoid cysts. Clinical evaluation and late surgical results. J Neurosurg 1977; 47: 12-18.

8. Lunardi P., Missori P. Supratentorial dermoid cysts. J Neurosurg 1991; 75: 262-266

9. El-Bahy K., Kotb A., Galal A., et al. Ruptured intracranial dermoid cysts. Acta Neurochir (Wien) 2006; 148: 457-462.

10. Liu J.K., Gottfried O.N., Salzman K.L., et al. Ruptured intracranial dermoid cysts: clinical, radiographic, and surgical features. Neurosurgery 2008; 62: 377-384.

11. Rai S.P. Ruptured intracranial dermoid cyst. Neurol India 2009; 57: 98-99.

12. Jamjoom A.B., Cummins B.H. The diagnosis of ruptured intracranial dermoid cysts. Br J Neurosurg 1989; 3: 609-612.

13. Kim I.Y., Jung S., Jung T.Y., et al. Traumatic rupture of an intracranial dermoid cyst. J Clin Neurosci 2008; 15: 469-471.

14. Oursin C., Wetzel S.G., Lyrer P., et al. Ruptured intracranial dermoid cyst. J Neurosurg Sci 1999; 43: 217-220.

15. Stendel R., Pietilä T.A., Lehmann K., et al. Ruptured intracranial dermoid cysts. Surg Neurol 2002; 57: 391-398.
16. Mann G.S., Gupta A., Cochrane D.D., et al. Occipital dermoid cyst associated with dermal sinus and cerebellar abscesses. Can J Neurol Sci 2009; 36: 487-490.

17. Martinez-Lage J.F., Ramos J., Puche A., et al. Extradural dermoid tumours of the posterior fossa. Arch Dis Child 1997; 77: 427-430.

18. Goffin J., Plets C., Van Calenbergh F., et al. Posterior fossa dermoid cyst associated with dermal fistula: report of 2 cases and review of the literature. Childs Nerv Syst 1993; 9: 179-181.

19. Tekkok I.H., Baeesa S.S., Higgins M.J., et al. Abscedation of posterior fossa dermoid cysts. Childs Nerv Syst 1996; 12: 318322.

20. Yang B., Jin H.M., Sun L.P., et al. Posterior fossa abscesses secondary to dermal sinus associated with dermoid cyst in children. Neuropediatrics 2008; 39: 39-42.

21. Wiemer D.R. An occipital dermoid tumor and sinus. Ann Plast Surg 1988; 21: 465-467.

22. Wilms G., Casselman J., Demaerel P., et al. CT and MRI of ruptured intracranial dermoids. Neuroradiology 1991; 33: 149-151. 